Bangladesh Journal of Anatomy January 2012, Vol. 10 No. 1 pp 20-22

\title{
Corticomedullary Index of Human Kidney
}

\author{
SM Nurul Hassan ${ }^{1}$, Waheeda Nargis ${ }^{2}$, Mansur Khalil ${ }^{3}$, Mohsin Khalili ${ }^{4}$ Md. Rafiqul Alam ${ }^{5}$
}

\begin{abstract}
Context: Due to increased incidence of renal disease affecting thickness of cortex \& medulla and their consequent increasing morbidity and mortality among our people, the present study was carried out to minimize the dependency on foreign standards and to evaluate corticomedullary index of human kidney collected from Bangladesh.
\end{abstract}

Objective: To study the age related changes of corticomedullary index.

Study type: Cross sectional analytical type of study.

Place and period of study: Department of Anatomy, Mymensingh Medical College, Mymensingh, Bangladesh from January 2004 to June 2005.

Materials and methods: $A$ total of 70 fresh human kidneys of both sexes and sides were collected from the morgue of Mymensingh Medical College at postmortem. The selected cases were between 5 to 60 years of age. The samples were divided into 3 different age groups ( $A$ : 05-15 years, B: 16-35 years, C: 3660 years) to observe the variations in corticomedullary index of kidney in different age groups.

Results: Among three groups, statistically significant $(P<.001)$ differences were found in the values of corticomedullary index between group $B$ and $C$ or also between group $C$ and $A$, the difference of values regarding corticomedullary index between group $A \& B$. But was not significant $(P>0.05)$.

Conclusion: There were changes in the corticomedullary index of kidney in different age groups.

Keywords: Kidney, Coticomedullary index.

\section{Introduction}

The kidneys maintain the balance of sodium and water in blood plasma, they also excrete toxic wastes $^{1}$. On coronal section the kidney presents two parts-outer renal substance and inner renal sinus $^{2}$. Renal substances consist of outer cortex and inner medulla. Cortex is granular in appearance and medulla presents renal pyramids which are conical masses ${ }^{3-8}$. Cortex which contains the glomeruli and the convoluted tubules can be distinguished from the medullary pyramids which has the loops of Henle, collecting ducts and collecting tubules ${ }^{5,9}$. Although the kidneys

1. Associate Professor \& Head, Department of Anatomy, Uttara Adhunik Medical College, Dhaka.

2. Associate Professor, Department of Biochemistry, Uttara Adhunik Medical College, Dhaka.

3. Professor \& Head, Department of Anatomy, Shahid Syed Nazrul Islam Medical College, Kishorganj.

4. Professor \& Head, Department of Anatomy, Mymensingh Medical College, Mymensingh.

5. Associate Professor (c.c.), Department of Anatomy, Dhaka Medical College, Dhaka

Correspondence: Dr. SM Nurul Hassan constitute $0.5 \%$ of the total body mass, they receive about $25 \%$ of the cardiac output. This richness of blood supply also makes the kidneys susceptible to toxic injuries by drugs and toxins. Of the amount of blood going to each kidney, $90 \%$ or more is distributed to the cortical area ${ }^{10}$. Thus the exposure to circulating toxic substance, culminating in loss of renal cells is greater for the cortex than medulla $a^{10-12}$. Renal mass increases from about $50 \mathrm{gm}$ at birth to more than $400 \mathrm{gm}$ during the third and fourth decades. By the ninth decade it declines to less than $300 \mathrm{gm}^{13}$. An increase in interstitial fibrosis may conceal some of the loss of substance. After the seventh decade, interstitial fibrosis becomes particularly pronounced in the medulla ${ }^{12}$.

Available articles are the evidences that human kidney has been widely studied in different races by various investigators. By studying kidney of different age groups, it is found that there are considerable structural and functional changes. 
These studies show normal growth process as well as degenerative changes after certain age ${ }^{10-13}$. But regarding corticomedullary index, very few research works has been performed on kidneys collected from Bangladesh. So this study was intended to evaluate the corticomedullary index of kidney with its changes in relation to age.

\section{Materials and Methods}

The present study was performed on 70 kidneys of both sexes and sides in the Department of Anatomy of Mymensingh Medical College. The samples were collected from unclaimed fresh dead bodies that underwent routine postmortem examination in the morgue of the Department of Forensic Medicine, Mymensingh Medical College from January 2004 to June 2005. The collected samples were divided into three age groups (Table-I). The samples were preserved in $10 \%$ formol saline and were washed with running tap water to avoid irritation of the eyes and nasal mucosa. Then the samples were taken in metallic tray and the surrounding fat and other unwanted structures were removed carefully. After these by a sharp knife, coronal section of kidney was done through the lateral border to the hilum passing from upper to lower pole. Then cortex and medulla of the renal substance were observed. Thickness of the cortex and medulla was measured at the same level with the help of divider and scale. In the same way thickness of cortex \& medulla was measured at three levels, and then their average thickness was calculated. Here the cortical thickness/medullary thickness ratio, is called the corticomedullary index and expressed as percentages, accordingly ${ }^{5}$.

\section{Table-I}

Distribution of the study samples in different age groups.

\begin{tabular}{lcc}
\hline Group & Age in years & Number of samples (\%) \\
\hline A & $05-15$ & $07(10 \%)$ \\
B & $16-35$ & $42(60 \%)$ \\
C & $36-60$ & $21(30 \%)$ \\
\hline Total & $05-60$ & $70(100 \%)$ \\
\hline
\end{tabular}

\section{Results}

Out of total 70 study samples the average corticomedullary index was approximately 36.76. The highest mean corticomedullary index was found in group A. Statistically highly significant $(<0.001)$ differences were found in the values of corticomedullary index between groups as well as among groups except the corticomedullary index between group $A$ and $B$ which was not significant (>0.05) (Table II, Table Illa and IIIb).

\section{Table-II}

Average thickness of cortex and medulla in different age groups.

\begin{tabular}{lcc}
\hline Group & $\begin{array}{c}\text { Thickness of } \\
\text { cortex }(\mathrm{cm})\end{array}$ & $\begin{array}{c}\text { Thickness of } \\
\text { medulla }(\mathrm{cm})\end{array}$ \\
\hline A & 1.02 & 2.61 \\
B & 1.80 & 4.70 \\
C & 1.54 & 4.68 \\
\hline Total & $1.02-1.80$ & $2.61-4.70$ \\
\hline
\end{tabular}

Table-IIla

Corticomedullary index of kidney in different age groups.

\begin{tabular}{lcc}
\hline Group & $\begin{array}{c}\text { Corticomedullary } \\
\text { index } \\
\text { Range }\end{array}$ & $\begin{array}{c}\text { Corticomedullary } \\
\text { Mean } \pm \text { SD } \\
\text { Range }\end{array}$ \\
\hline A & $36.58-41.58$ & $39.08 \pm 1.88$ \\
B & $35.04-41.54$ & $38.29 \pm 1.63$ \\
C & $29.75-36.05$ & $32.90 \pm 1.50$ \\
\hline Total & $29.75-41.58$ & $36.76 \pm 1.67$ \\
\hline
\end{tabular}

$\mathrm{SD}=$ Standard division

Table-IIIb

Statistical analysis of table IIIa

\begin{tabular}{lcc}
\hline Group & \multicolumn{2}{c}{ Corticomeullary index } \\
& P value & Inference \\
\hline A vs B & $>0.05$ & NS \\
B vs C & $<0.001$ & HS \\
C vs A & $<0.001$ & HS \\
\hline
\end{tabular}

Statistical analysis was done by ANOVA, NS = not significant, $\mathrm{HS}=$ highly significant 


\section{Discussion}

In this present study, corticomedullary index ranged from 29.75 to 41.58 and group A presented with maximum mean corticomedullary index where as group $C$ found to show the lowest mean corticomedullary index. These findings indicate that the highest corticomedullary index is confined to younger age group (upto 15 years) and lowest corticomedullary index being observed at elderly (upto 60 years) age group. Corticomedullary index at middle age group (upto 35 years) found almost similar to that of younger age group which is supported by the reports of Sultana ${ }^{14} \&$ Alam $^{15}$ that the kidney mass increases with increasing age upto 35 years and gradually decreases along with the increase of age particularly after 40 years, which may be a reflection of senile changes of the kidney and this was also correlated with the finding reported by Anderson \& Brenner ${ }^{13}$. Human kidneys loss approximately one fifth of their mass between fourth to eighth decades of life. Cortex is affected more than medulla. An increase in interstitial fibrosis may conceal some of the loss of substance. After the seventh decade, interstitial fibrosis particularly pronounced in medulla ${ }^{12}$. So in our study, presenting lowest mean corticomedullary index at elderly age group could be explained by the findings reported by Maclachlan ${ }^{12}$.

In this study corticomedullary index of the kidneys in relation to various age groups was observed as well as changes of it among the age groups had been marked. The cause of increase or decrease of morphological parameter at different periods of life might be related to the increase or decrease in body surface area as well as renal mass with age ${ }^{16}$.

\section{References}

1. Larsen WJ. Anatomy: development, function, clinical correlations. Philadelphia: Saunders; 2002:262.

2. Martini FH, Timmons MJ, Mckinley MP. Human anatomy. $3^{\text {rd }}$ ed. New Jersey: Prentice Hall, Inc; 1995:688-95.
3. Datta AK. Essentials of human anatomy (part1). $8^{\text {th }}$ ed. Calcutta: Current Books International; 2008: 294-95.

4. Snell RS. Clinical anatomy. $9^{\text {th }}$ ed. Baltimore: Lippincott Williams and Wilkins; 2012: 207.

5. Standrings, Ellis H. Healy JC, Johnson D, William A, editors, Gray's Anatomy. $39^{\text {th }}$ ed. London: Churchill Livingston; 2005: 487,273.

6. Mazumdar S. Anatomy at a glance. $1^{\text {st }}$ ed. New Delhi: Jaypee Brothers Medical Publishers (P) Ltd; 2009:170-171.

7. Romanes GJ. Cunningham's manual of practical anatomy (vol. 2). 15 th ed. New York: Oxford University press Inc; 1986: 169.

8. Sinnatamby CS. Last's anatomy regional and applied. $11^{\text {th }}$ ed. UK: Churchill Livingstone Elsevier; 2006: 295.

9. Jacob S. Atalas of human anatomy. $1^{\text {st }}$ ed. UK: Churchill Livingstone; 2002: 126.

10. Cotran RS, Kumar V, Collins T. Robbin's Pathologic Basis of Disease. $6^{\text {th }}$ ed. Philadelphia: WB Saunders Company; 1999: 931-34.

11. Nahas AME. Plasticity of kidney cells: Role in kidney remodeling and scarring. Kidney international 2003; 64: 1553-63.

12. McLachlan MSF. The aging kidney. Lancet 1978; 11:143-46.

13. Anderson $S \&$ Brenner BM. Effect of aging on the renal glomerutus. AM J Med 1986; 43537.

14. Sultana Z. Anatomical study of human postmortem kidney in Bangladeshi people (thesis). Dhaka: Institute of postgraduate medicine and research; 1991.

15. Alam MZ. Gross morphological and histological features of the kidneys in Bangladeshi people (thesis). Dhaka: Institute of postgraduate medicine and research; 1994.

16. Walsh PC, editor. Campbell's urology (V-1). $8^{\text {th }}$ ed. Philadelphia: Saunders; 2002:19-35. 